\title{
Learning Model of Picture Symbols in Improving Language Skills in Early Children
}

\author{
Jenny I Dengah \\ Department of Early Childhood Teacher Education \\ Universitas Negeri Manado, Indonesia \\ ikedengahfip2019@gmail.com
}

\begin{abstract}
This study aims to describe the method of symbol symbols in improving language skills listening to early childhood. The research method used is the action research method, by carrying out two cycles. with media images show an increase in children's learning outcomes in each cycle, both in cycle I and cycle II. Improved learning outcomes of the subject of the discussion of the use of the symbol method in improving language skills listening to early childhood can be seen in the average score of development in the cycle I-, cycle II-, and from the cycle experienced an increase in the average child development outcomes of early childhood developmental outcomes obtained each cycle. This is due to several things that support the process of learning activities. Based on the results of observations on early childhood in the use of the symbol method to improve their language skills listening to media images in cycle I and cycle II shows the activeness of students who number 12 children with a percentage of $100 \%$ active early childhood.
\end{abstract}

Keywords: image symbol, speaking and listening

\section{INTRODUCTION}

Children are little people who have potential that still needs to be developed or formed. Children have certain characteristics that are unique and not the same as adults, they are always active, dynamic, enthusiastic and curious about what is seen, heard, felt, as if they never stop exploring and learning. Early childhood education is a form of education that focuses on laying the foundation for physical growth and development (fine and gross motor coordination), intelligence (power of thought, creativity, emotional intelligence, spiritual intelligence), socio emotional (attitude and behavior as well as diverse), language and communication, according to the uniqueness and stages of development that are passed by early childhood.

Early childhood education programs are planned, developed, managed and evaluated with models and approaches that are very specifically tailored to the characteristics of the students' subject in this case the child. This specially designed children's education certainly requires a broad and complete understanding of the teachers so that mistakes that occur such as teachers assume that educational programs for anyone essentially the same, do not happen again.

The application of educational programs that are specific to children, will also affect the demands of teacher understanding to see the educational process in children as a system which consists of various interrelated elements. Understanding the process of children's education as a system Learning language is essentially learning communication. Therefore, language learning is directed to improve students' ability to communicate, both oral and written (Depdikbud, 1995).

This is relevant to the 2004 curriculum that language learning competencies are directed into four sub-aspects, namely listening, speaking, reading, and writing. Therefore, every teacher must have skills in choosing learning strategies for each type of learning activity.
Thus, the selection of appropriate learning strategies in learning activities, is expected to achieve learning objectives can be met. Gilstrap and Martin (1975) state that the role of the instructor is more closely related to learning success, especially with regard to the ability of teachers to determine learning strategies. Whereas the purpose of language learning, according to Basiran (1999) is communication skills in various communication contexts.

According to Sukarno in Trianto (2007) the learning model is a conceptual framework that describes certain procedures systematically in organizing learning experiences to achieve certain learning goals, is a guide for learning designers and instructors in carrying out teaching activities. Mills argues in Suprijono (2009) that a model is a form of accurate representation as an actual process that allows a person or group of people to try to act on that model.

According to Arend in Suprijono (2009), the learning model refers to the approach to be used, including learning objectives, stages in learning activities, learning environment, and classroom management. According to Hamid (2011) this model is "a learning model in which the teacher uses tools to explain a material and embed a message in the material. By using aids or drawing media, children are expected to be able to follow the lessons with good focus and pleasant conditions. So that any message delivered can be well received and able to sink in the heart and can be recalled by the child.

\section{METHOD}

The research used in this study is Classroom Action Research which refers to the Kemmis and MC Taggart models in Aqib (2006), which consists of four stages, namely: (1) the preparation / planning stage; (2) stage of implementation / action; (3) observation stage; and (4) reflection. The subject of this study were students in TK GMIM BAITANI LIBAS with 12 children consisting of 
4 boys and 8 girls. The time of the research was on 2 MAY 2018 to 2 JUNI 2018.

Data collection techniques used in this study are observations (observations) and student learning outcomes test. Data collection by observation techniques using the observation format. The observation format is used to describe the process and product of children's listening skills learning by using the symbol learning model. The observation format is also used to record the reflections of researchers and collaborators on the learning process and products.

Data collection techniques were taken with observation techniques, in this study the researchers prepared observation sheets using the star symbol to assess the development of students $\left(^{*}\right)$, namely: Not Developing (BB), Starting to Develop (MB), Developing Expectations (BSH) and Developing Very Good (BSB).

\section{RESULTS}

Cycle I

Based on the results of the evaluation through LKS and the activities carried out by children in the learning process in cycle 1 of the total number of 12,10 children were present, and those who succeeded in this cycle 1 , were 2 people, 10 people were unsuccessful and got an average grade $63 \%$.

\section{Cycle II}

Based on the observations of researchers, that children have changes in learning. Thus, the use of the symbol learning model in drawing can activate, motivate, and encourage children to improve their language skills in listening to Early Childhood well, in children in kindergarten GMIM BAITANI LIBAS. Even if there is still one group that has difficulty in drawing this based on the observation that there is no togetherness of children because they tell more. From the number of 12 children there are still 6 children, namely children from group 2 who need to get the attention and direction of the teacher.

Based on the results of the evaluation through the worksheets and activities carried out by children in the learning process in cycle 1 of the total 12, there were 10 children present, and those who succeeded in this cycle 1 were 2 people who had not succeeded 10 people and received an average score of average $63 . \%$.

\section{DISCUSSION}

The condition of the class at the beginning of learning language skills before using the method of learning symbol images in children in kindergarten GMIM BAITANI LIBAS shows a classroom atmosphere that is too monotonous so that early childhood understanding of the activity of learning material is a bit difficult to understand by children. In the process of teaching and learning, it should be endeavored to provide a new atmosphere and situation that can facilitate understanding of language concepts and can also improve early childhood learning outcomes.

According to Surya (2004) behavioral change as a result of learning is a whole-range behavior covering all aspects. Meanwhile according to Sudjana (2005) learning outcomes are abilities students possess after they have received their learning experience.
At the beginning of the use of the symbol method with image media, there were still some children who were mistaken in sorting the series drawings because everyday children did not really understand how learning in using picture media. But at the next meeting the teacher was even more innovative by giving reinforcement to the children by communicating. The application of the symbol drawing method in improving children's listening language skills with this drawing medium engages all early childhood children to be active in ongoing learning.

The activity begins to appear when there are children who dare to the front of the blackboard and paste the pictures into a logical sequence. When sorting pictures, there is interaction between early childhood and the teacher. This is very important so that all early childhood can understand, master and develop the concept of the activity being studied. Based on the results of research in kindergarten GMIM BAITANI LIBAS by using the symbol method to improve language skills in listening to early childhood with picture media shows an increase in children's learning outcomes in each cycle, both in cycle I and cycle II.

Improved learning outcomes of the subject of the discussion of the use of the symbol method in improving language skills listening to early childhood can be seen in the average score of development in the cycle I-, cycle II, and from the cycle experienced an increase in the average child development outcomes of early childhood developmental outcomes obtained each cycle. This is due to several things that support the process of learning activities. Based on the results of observations on early childhood in the use of the symbol method to improve their language skills listening to media images in cycle I and cycle II shows the activeness of students who number 12 children with a percentage of $100 \%$ active early childhood.

Children become more active because they feel challenged to understand learning activities and develop abilities within themselves when the KBM process is taking place. As according to Surya (2004) learning is a process carried out by individuals to obtain a change of behavior as a whole, as a result of the experience itself in interaction with the environment, while the teacher acts as a motivator and facilitator as Hasibuan (2006) which states that, teaching is the creation of an environmental system that enables the learning process.

\section{CONCLUSION}

The use of symbol images in improving the development of language Listening to Early Childhood in kindergarten GMIM BAITANI LIBAS. The use of image symbol models in improving children's language development in making children active, creative, and motivated because the teacher is able to use the image symbol learning model appropriately.

\section{REFERENCES}

[1] Jihad. 2008. Penilaian Hasil Proses Belajar Mengajar. Bandung : PT Remaja Rosdakarya.

[2] Oemar Hamalik. 2003. Proses Belajar Mengajar. Jakarta: Bumi Aksara. 
[3] Sanjaya, Wina. 2008. Strategi Pembelajaran. Kencana: Jakarta.

[4] Sudijono, Anas. 2010. Pengantar Statistik Pendidikan. Jakarta: Rajawali Pers.

[5] Sudjana, Nana. 2006. Penilaian Hasil Proses Belajar Mengajar. Bandung: PT Remaja Rosda Karya.

[6] Sudjana. Nana. 2006. Penilaian Hasil Proses Belajar Mengajar. Bandung: PT Remaja Rosda Karya.

[7] Sudjiono. 2007. Kriteria Penilaian Hasil Belajar. Kencana: Jakarta.

[8] Sugiyono. 2012. Metode Penelitian Pendidikan (pendekatan kualitatif, kuantitatif, dan $R \& B$ ). Bandung: Alfabeta.

[9] Suparno. 2006. Artikel Penelitian Tentang Model Pembelajaran Inquiri. Jakarta: Rineka Cipta.
[10] Suprijono, Agus. 2009. Cooperatif Learning Teori dan Aplikasi PAIKEM. Surabaya : Pustaka Pelajar.

[11] Trianto. 2009. Mendesain Model Pembelajaran InovatifProgresif. Jakarta: Balai Pustaka.

[12] Usman. 2008. Penelitian Tindakan Kelas. Darussalam: Universitas Syiah Kuala.

[13] W. Gulo. 2008. Strategi Belajar Mengajar. Jakarta: Gramedia Widisarana Indonesia.

[14] Wardhani, I., \& Kuswaya Wihardit, 2008. Penelitian Tindakan Kelas, Jakarta: Universitas Terbuka.

[15] Yus, Anita. 2005. Penilaian Perkembangan Belajar Anak Taman Kanak-Kanak. Jakarta: Diretur Pembinaan Pendidikan Tenaga Kependidikan dan Ketenagaan Perguruan Tinggi. 